\title{
Kształtowanie struktur urbanistycznych na terenach zagrożonych smogiem i zanieczyszczeniem powietrza
}

\section{Shaping urban structures in the areas threatened by smog and air pollution}

Streszczenie

Niniejszy artykuł stanowi przegląd rozwiązań urbanistycznych mających zastosowanie w walce z problemem smogu oraz zanieczyszczenia powietrza w mieście. Autorka przedstawia sposoby kształtowania przestrzeni miejskiej, wprowadzając wiele zabiegów urbanistycznych, architektonicznych, strategicznych oraz funkcjonalnych, mających na celu polepszenie jakości powietrza. Ich funkcjonowanie argumentuje działaniem pionierskich realizacji, wdrożonych w życie.

Słowa kluczowe: smog, zanieczyszczenie powietrza, rozwiązania urbanistyczne, modernizacja miast, środowisko miejskie, procesy urbanizacyjne, urbanistyka

\section{Abstract}

This article is an overview of urban solutions applicable in the fight against the problem of smog and air pollution in the city. The author presents ways of shaping the urban space by introducing a number of urban, architectural, strategic and functional processes aimed at improving air quality. Their function is argued for pioneering works which were put into effect.

Keywords: smog, air pollution, urban solutions, city modernization, urban environment, urbanization processes, urbanity 


\section{WSTĘP}

Każda struktura urbanistyczna, zarówno będąca terenem miejskim, jak i wiejskim, złożona jest z wielu tkanek, w których rozwój cywilizacji wywołuje zarówno pozytywne, jak i negatywne skutki w ich funkcjonowaniu. Samorządowcy, którzy sprawują pieczę na danym terenie, muszą zagwarantować mieszkańcom jak najlepsze warunki do życia, zapewniając w miarę swoich możliwości potrzeby socjalne, modernizację infrastruktury, bezpieczeństwo oraz rozwój terytorium. Jednakże coraz częściej zdarza się, że postępująca urbanizacja przekracza możliwości bezpiecznego funkcjonowania siedliska w ekosystemie. Problem ten pojawia się najczęściej w obrębie struktur miejskich, gdzie wskaźniki skażenia powietrza przekraczają normy. Brak wystarczającej kontroli nad rozrastaniem się oraz funkcjonowaniem przemysłu, nieprzemyślane pozwolenia na inwestycje, źle rozplanowana komunikacja czy też niewielka wiedza mieszkańców w temacie ekologii to podstawowe błędy, które najczęściej są powodami pojawienia się zanieczyszczenia powietrza. W rezultacie jednostka urbanistyczna bierze czynny udział w procesie degradacji własnego terytorium, co bezpośrednio wpływa na jakość życia społeczeństwa.

Objawami niepoprawnego funkcjonowania miasta są: złe samopoczucie, choroby i zwiększona umieralność społeczeństwa, niszczenie budynków oraz infrastruktury, pogarszanie się warunków klimatycznych oraz wiele innych problemów zarówno pośrednio, jak i bezpośrednio wpływających na warunki bytowe. Aby uniknąć dynamizacji procesu suburbanizacji, konieczna będzie zmiana sposobu myślenia oraz interdyscyplinarne podejście do kwestii skażenia środowisk miejskich. Wprowadzenie reguł rozwoju zrównoważonego oraz korekt związanych z organizacją panującą w mieście, są jednymi z wielu sposobów na rozwiązanie problemu zanieczyszczenia powietrza.

\section{JAK, GDZIE I KIEDY POJAWIA SIĘ PROBLEM?}

Zanieczyszczenia powietrza powstają w obrębie ośrodków przemysłowych, w okolicy szlaków transportu mechanicznego oraz przede wszystkim na terenach mieszkalnych, gdzie systemy grzewcze oraz paliwa używane do ich zasilania są niezgodne z normami ekologicznymi, przyczyniając się do powstania zjawiska niskiej emisji. Istnieją także ruchy mas powietrza, które sprowadzają zanieczyszczenie z okolicznych wiosek lub miast. Efektem gromadzenia się spalin w przestrzeni miejskiej jest smog. Jest to zjawisko występowania rdzawobrunatnej mgły o charakterystycznym, nieprzyjemnym zapachu. Smog jest wynikiem reakcji połączenia czynników związanych z topografią terenu, zjawiskami atmosferycznymi oraz mieszanką szkodliwych związków chemicznych rozpylonych w powietrzu; są to m.in. tlenki siarki, azotu, węgla, sadze oraz różnego rodzaju pyły. Układ wyżowego ciśnienia powoduje inwersję temperatury, czyli unoszenia się ciepłych mas powietrza nad 
zimnymi. W warstwie mieszania się skrajnych temperatur, w połączeniu z czynnikami wyżej wymienionymi, powstaje zjawisko, które w niepożądany sposób wpływa na złą kondycję miasta i ich mieszkańców ${ }^{1}$.

\section{CO MOŻE ZROBIĆ ARCHITEKT/URBANISTA?}

Przed podjęciem się tworzenia opracowania projektowego architekci oraz urbaniści powinni zdobyć jak najwięcej informacji o terenie. Analizy dotyczące identyfikacji źródeł zanieczyszczeń oraz ich rozprzestrzenianiu powinny być oparte na badaniach z pozyskanych materiałów wyjściowych, a także prac projektowych i studiów² ${ }^{2}$ Kompleksowość analiz będzie uzyskana tylko wtedy, gdy będą one sporządzone w oparciu o karty interdyscyplinarne, które wyczerpująco dostarczą informacji pod względem tematycznym, szczegółowości, wiarygodności czy też kompletności ${ }^{3}$. W pracy analitycznej projektantom będą potrzebne dane z zakresu urbanistyki, kartografii czy też meteorologii. Dobrymi źródłami, które dostarczą nam informacji na temat obszaru, będą również publiczne publikacje o danych przestrzennych, takie jak m.in. Geoportal.

Projektant badający teren zagrożony skażeniem powinien uwzględnić w szczególności czynniki istotne w zapobieganiu zanieczyszczeniom powietrza. Informacje na temat zmiennej jakości powietrza w ciągu doby, w konfrontacji z kontrolą emisji zanieczyszczeń powietrza z zakładów przemysłowych lub też lokalizacją najgęstszego ruchu ulicznego, będą kluczową informacją w trakcie procesu projektowania. Ważne jest także uwzględnienie topografii terenu; szorstkość podłoża lub jego chropowatość wpływają na rozprzestrzenianie się zanieczyszczeń. Istotne także będzie określenie kierunku przedłużenia pierzei zielonych oraz lokalizacja głównych arterii przewietrzania miejskiego i kierunków wiatru, w których odbywa się wymiana powietrza. Kluczowym zagadnieniem będzie też określenie wysokości oraz gęstości zabudowy, które mogą stanowić bariery architektoniczne dla przepływu powietrza. Analiza komunikacyjna zidentyfikuje najczęściej używane drogi, nad którymi generują się siedliska spalin. Warto także ocenić warunki położenia obszaru pod szerszym kątem niż lokalny. Wpływ na funkcjonowanie miasta może mieć także jego bliższe i dalsze otoczenie.

Planiści, którzy podjęli się badania przestrzeni, muszą wziąć pod uwagę nie tylko to, jak prezentuje się aktualna sytuacja na danym terenie; ważne jest także poznanie genezy terytorium oraz planów co do jego przyszłości. Dzięki temu można sporządzić prognozy oraz określić szanse na jego rekultywację. Wykonanie analiz urbanistycznych może zająć dużo czasu, jednakże pominięcie jakiegokolwiek aspektu może spowodować niepowodzenie projektu. Projektanci wtenczas poszukują odpowiedzi na pytania, których odpowiedzią będą konkretne plany działania. Przewidują, czy zmiany, które chcą wprowadzić, będą owocne i nie zaszkodzą strukturze miejskiej ${ }^{4}$. 
Kolejnym etapem działania będzie określenie rozwiązań w oparciu o analizy. Urbaniści mogą ograniczać emisję zanieczyszczeń poprzez określenie ustaleń w planach zagospodarowania miejscowego, które każdy budynek powinien spełnić, by nie tworzył zagrożenia dla generowania lub kumulowania skażeń. Architekci, dzięki wytycznym urbanistów, mogliby formować budynki tak, by były one nieszkodliwe w aspekcie funkcjonowania miasta, a nawet propagować rozwiązania proekologiczne. Dzięki użyciu nowoczesnych technologii budownictwa można zmodernizować stare budynki, a nowe realizacje mogłyby zapoczątkować trend powstawania budowli energooszczędnych ${ }^{5}$. Istotnym elementem jest także informowanie i kształcenie społeczeństwa na temat przemian w środowisku, które będzie brało udział w tym przedsięwzięciu. Rozmowy z przedstawicielami społeczności, otwarte dyskusje oraz inne formy informacji o procesach rekultywacyjnych dadzą obraz mieszkańcom, że warto jest zatroszczyć o wspólne dobro.

\section{JAK DZIAŁAĆ W SKAŻONYM ŚRODOWISKU?}

Polityka przestrzenna miast bywa różna. W większości miast planowanie przestrzenne odbywa się nie do końca konsekwentnie, a czasem w oparciu tylko o zyski niosące z rozrostu tkanek oraz ich coraz intensywniejszej zabudowy. Jednakże urbanista, powołany do pracy nad projektem poprawy jakości powietrza, posiada całe spektrum narzędzi planistycznych, które może wprowadzić, by ówczesny stan uległ polepszeniu.

Narzędzia te obejmują działania na strukturach funkcjonalnych, przestrzennych oraz rodzajowych miasta, gdzie szczególny nacisk kładzie się na uwarunkowania fizyczne i geograficzne terenu ${ }^{6}$. Poniżej wymienione elementy strategii są tymi sugerowanymi do uwzględnienia w pracy projektowej.

a) Przewietrzanie miejskie:

- określenie istniejących i wyznaczenie potencjalnych ścieżek wietrzenia miejskiego - wyznaczone wzdłuż obszarów dolin rzecznych, wód powierzchniowych, obszarów ochrony ekologicznej, obszarów o zabudowie luźnej lub jej braku,

- zidentyfikowanie dominujących wiatrów, które mogą sprowadzić zanieczyszczenie na teren, a także pomóc im się przemieszczać i rozprzestrzeniać,

- ustalenie położenia układów urbanistycznych względem stron świata, określenie gradacji wysokości i gęstości budynków, które mogą stanowić bariery architektoniczne dla przepływu powietrza ${ }^{7}$,

- określenie odległości od stref przemysłowych kompleksów mieszkaniowych i biurowych,

- zaplanowanie stref ochronnych w postaci zielonych barier, które będą izolowały napływ spalin do wnętrza założeń ${ }^{8}$,

- zlokalizowanie zakładów przemysłowych na mapie miasta oraz określenie ich wpływu na otoczenie, wyznaczenie stref przemysłowych, w których wprowadzona będzie monokultura funkcjonalna ${ }^{9}$, 
- sprecyzowanie wymagań dotyczące powstawania nowych budynków, które mają powstać w strefach buforowych przewietrzania miejskiego,

- wprowadzenie większej ilości uwarunkowań w planach zagospodarowania przestrzennego dotyczących kubatury oraz wydajności energetycznej budynków,

- wzmożenie kontroli stanu technicznego budynków przez samorządy,

- uwzględnienie ochrony prawnej odnośnie terenów wolnych od zabudowy ${ }^{10}$.

b) Zieleń i woda:

- racjonalne gospodarowanie przestrzenią w oparciu o sytuowanie zieleni, z uwzględnieniem mikroklimatu, regulacji temperatury powietrza, powstrzymywania hałasu, ograniczania nasłonecznienia i zacieniania, oczyszczania powietrza oraz hamowania przemieszczania się spalin,

- precyzowanie kształtu, rodzaju oraz gradacji wysokości zieleni w obrębie założeń urbanistycznych, z uwzględnieniem kształtu tkanek urbanistycznych,

- określenie minimalnej procentowej wartości powierzchni biologicznie czynnej, zarówno dla budynków istniejących, jak i nowo powstających,

- wyznaczenie stopnia możliwości przekształcenia istniejącej zieleni, kontrola nad jej stanem technicznym,

- formowanie zieleni w bufory hamujące lub rozpraszające zanieczyszczone powietrze w obrębach zabudowy mieszkaniowej oraz miejsc pracy,

- aranżowanie powierzchni wolnej w mieście od zabudowy w celu zaaranżowania na niej przestrzeni rekreacyjnej, która również stanie się buforem migracji powietrza ${ }^{11}$,

- unikanie formowania alei drzew w zielone tunele wzdłuż alei komunikacyjnych ${ }^{12}$,

- ochrona przed zabudową naturalnych korytarzy zieleni i wody,

- sytuowanie w obrębach struktur zabudowy miejsc z zielenią niską, które będą stanowiły miejsca wymiany powietrza ${ }^{13}$,

- umieszczanie zieleni na budynkach w postaci zielonych dachów, ogródków piętrowych, zielonych elewacji jako substytut na terenach, gdzie zabudowa jest zwarta ${ }^{14}$,

- tworzenie sztucznych zbiorników wodnych, które będą zarówno atrakcją dla kompleksów architektonicznych, jak i elementem zwalczającym smog ${ }^{15}$.

c) Infrastruktura

- zawarcie idei energooszczędności, ekologiczności oraz kompozycji, która nie będzie stanowiła barier dla rozwoju naturalnego waloru miasta,

- utrzymanie zasad przepływu powietrza poprzez aranżowanie nowych struktur urbanistycznych regulujących tkankę miejską,

- eliminowanie powstawania tzw. bram miejskich - kompleksów wysokich budynków biurowych na obrębach miast - stanowiących bariery dla wymiany powietrza, aranżowanie aerodynamicznych układów równoległych względem kierunku wiatru ${ }^{16}$,

- wypełnianie luk w zabudowie, stwarzających okazję do powstawania wirów powietrznych, eliminowanie oporu aerodynamicznego ${ }^{17}$, 
- unikanie formowania korytarzy wzmagających prędkość wiatru wzdłuż ciągów ulicznych - wzrasta ryzyko powstania zjawiska przeciągu miejskiego, który może zasysać zanieczyszczenia,

- integracja struktury miejskiej z zielenią śródmiejską i pozamiejską,

- aranżowanie obiektów wysokich w obłe kształty, niestanowiące bariery dla wiatrów poruszających się w wyższych partiach troposfery,

- rozproszenie względem siebie budynków wysokich ${ }^{18}$,

- eliminowanie w mieście powstawania wysp ciepła, które zasysa zimne i chłodne powietrze z obrzeży - sytuacja osłabionej konwekcji powietrza kreuje warunki do powstania siedliska smogu ${ }^{19}$,

- próby z rozwiązaniem problemu niskiej emisji wielkoobszarowej: inwestycje w powstanie lub poszerzenie sieci ciepłociągowej, dofinansowania do wymiany pieców grzewczych, sankcje karne przy nieodpowiednim ogrzewaniu budynków ${ }^{20}$.

d) Komunikacja

- wprowadzenie większej ilości rozwiązań alternatywnych sposobów komunikacji bezpośredniej, tj. ścieżki rowerowe, ścieżki piesze ${ }^{21}$,

- rozbudowa infrastruktury transportu publicznego oraz jej urozmaicenie w postaci stopnia prędkości oraz dostępności, przewidzenie potencjalnej liczby użytkowników przestrzeni oraz zaaranżowanie jej zgodnie z potrzebą ${ }^{22}$,

- utrzymanie konwencji proekologicznej w postaci wprowadzenia masowego transportu elektrycznego, np. szybka kolej aglomeracyjna czy też metro,

- wprowadzenie taniego transportu zbiorowego, o urozmaiconym rozkładzie jazdy ${ }^{23}$,

- nadanie terenom śródmiejskim ograniczeń w postaci regulacji prędkości ruchu kołowego, wykluczenia silników spalinowych, zamknięcia lub ograniczenia ruchu w danych strefach, wprowadzenie wysokich stawek za parkowanie w mieście ${ }^{24}$,

- wprowadzenie systemu „park and ride”25,

- dbałość o stan techniczny dróg oraz ścieżek przez samorządy.

e) Architektura:

- propagowanie wśród społeczności budowanie domów w oparciu o proekologiczne zastosowania budowlane, tzw. domy pasywne, zmodernizowanie systemów ogrzewania, np. wykorzystanie pompy ciepła czy panelów solarnych ${ }^{26}$,

- tworzenie budynków użyteczności publicznej w oparciu o wymagania certyfikatów, które określają normy budownictwa ekologicznego, np. Certyfikat LEED ${ }^{27}$,

- aranżowanie zielonych elewacji i dachów zarówno na starych, jak i nowych budynkach, termomodernizacje z systemami pochłaniania zanieczyszczeń ${ }^{28}$,

- wprowadzenie elementów małej architektury, np. wieże antysmogowe, ekrany pochłaniające spaliny, panele przeciwpyłowe ${ }^{29}$.

Wprowadzenie wszystkich wymienionych zaleceń do struktury miejskiej może trwać niestety latami, jednakże warto myśleć o mieście z perspektywą. Wizję idealnego miasta, 
w którym elementy te zostały wprowadzone, można obejrzeć w koncepcyjnych projektach wybitnego francuskiego architekta, Vincenta Callebauta. Jego awangardowe pomysły na całkowite przearanżowanie struktur miejskich są warte naśladownictwa, mimo że wydają się utopijne. Projekt, który opracował dla Paryża (II. 1), zakłada całkowite przekształcenie ówczesnej struktury miasta. Inteligencja projektowanych budynków miała objawić się w połączeniu podstawowych funkcji budynku z funkcją dodatkową, między innymi antysmogową. Budynki w jego ideach zawierały instalacje: fotowoltaiczne, uzyskujące energię z wody deszczowej czy też wieże z bioreaktorami z alg. Głównym i dominującym elementem w jego projektach budynków jest wplatanie zieleni w każdy zakątek. Niektóre propozycje budynków sugerowały także utworzenie na ich obszarze farm i ogrodów ${ }^{30}$.

\section{PRZYKŁADY WPROWADZONYCH TECHNIK WALKI ZE SMOGIEM}

Na świecie jest wiele miast, których problem smogu dotknął stosunkowo dawno, a ich walka z nim trwa już od dłuższego czasu. Objawia się ona w różny sposób, począwszy od niewielkich zmian w organizacji ruchu czy popularyzacji środków komunikacji publicznej lub rowerowej, skończywszy na kreowaniu całych koncepcji miast, które mają już od samego powstania być odpornymi na smog.

Miasto Czandigarh to jeden z przykładów, który może wykorzystać ukształtowanie terenu, by zminimalizować problem smogu. Miasto to od dawna boryka się z intensywnym zanieczyszczeniem powietrza. Ratunek miały przynieść analizy wietrzenia miejskiego oraz wpływ lokalnych wiatrów na wymianę powietrza. Okazało się, że wiatr górski pomaga w szybkim rozproszeniu dymu i innych cząstek stałych w powietrzu nad miastem ${ }^{31}$.

Kraków, miasto o niskim procencie udziału zieleni miejskiej, opracowuje plan zagospodarowania przestrzennego bulwarów Wisły, które mają pozostać głównym korytarzem przewietrzania miejskiego oraz miejscem rekreacji dla mieszkańców. Miasto wszczęło również wiele akcji promocyjnych polegających na sadzeniu drzew oraz rozdawaniu roślin doniczkowych. Ruch oparty na ochronie terenów zielonych w mieście jest bardzo popularny - Stowarzyszenie Łąk Nowohuckich staje coraz częściej w obronie terenów ważnych dla krajobrazu miasta. Aktywność społeczna takich organizacji i ich świadomość działania intensywnie pogłębia wiedzę na ten temat wśród mieszkańców ${ }^{32}$.

Przykładami na walkę ze smogiem w kwestii ograniczenia transportu będą miasta europejskie. Madryccy urbaniści pracują nad przeprojektowaniem 24 ulic, które najbardziej odczuwają nasilenie ruchu. Dla kierowców oznaczałoby to też, że zmiany w organizacji ruchu wprowadzą różne sankcje, za których nieprzestrzeganie przewidziana będzie wysoka kara. Hamburg oraz Kopenhaga (II. 2) to miasta, które pracują nad tym, by polepszyć w swoim mieście infrastrukturę dla pieszych i rowerzystów. 
Miasto, które odniosło największy sukces po wprowadzeniu ograniczeń ruchu, to Paryż. Zanieczyszczenie spadło o 30\% tuż po wprowadzeniu sankcji w niektórych częściach miasta. Teraz planowane jest całkowite zamknięcie wstępu dla kierowców do centrów miast. Ograniczenia pojawiają się również dla właścicieli silników Diesla - w niektóre obszary miejskie nie mają one dostępu, a każde przekroczenie zakazu jest karalne ${ }^{33}$. Szwedzkie Malmö jest kolejnym miastem, które walczy ze smogiem. W planie przearanżowania centrum miasta duży nacisk kładzie się na ograniczenia ruchu drogowego, głównego źródła emisji i zanieczyszczenia powietrza. Miasto wdrożyło nowe pasy autobusowe dla transportu publicznego, przebudowało drogi i obniżyło ograniczenie prędkości z 50 do 40 kilometrów na godzinę. Również władze Rzymu wprowadziły wiele zabiegów, m.in. wprowadzenie systemu „park and ride" oraz modernizacja metro ${ }^{34}$.

Nowoczesna zabudowa oparta o nurt zrównoważonego projektowania tkanki miejskiej nie ominęła także Mediolanu. Bosco Verticale (II. 3, 4) to kompleks dwóch luksusowych budynków mieszkaniowych, zaprojektowanych przez Stefano Boeriego. Budynek charakteryzuje się żyjącą elewacją - na balkonach budynku rosną rośliny wyłapujące zanieczyszczenia z powietrza. Odmiany roślin zostały dobrane tak, by mogły funkcjonować w każdych warunkach nasłonecznienia, były łatwe w utrzymaniu oraz poprawiały jakość powietrza mieszkań$\mathrm{com}^{35}$. Budynków tego typu powstaje coraz więcej - nie tylko ze względu na ich interesującą formę, ale przede wszystkim ideę, która im przyświeca. Elementem architektury modernizowanej o nowoczesną instalację jest Szpital im. Manuela Gea Gonzaleza w Mexico City (II. 5). Od kilku lat budynek jest w posiadaniu nietypowej elewacji. Zaprojektowana została ona przez pracownię Elegant Embellishments z Berlina i nie odbiega ona od wyglądu dzieła sztuki; ażurowe panele w kolorze białym imitują w kształcie plastry miodu. Powierzchnie instalacji zostały pokryte zostały dwutlenkiem tytanu, który wystawiony na słońce neutralizuje szkodliwe związki chemiczne ${ }^{36}$.

Przykładem wdrożenia w tkankę miejską nowoczesnych technologii małej architektury będzie Modena we Włoszech. Miasto podjęło się testowania nowego rozwiązania - CityTree (II. 6). Jest to specjalna konstrukcja pochłaniacza zanieczyszczeń w formie ściany z mchu. Producenci gwarantują, że CityTree może zastąpić pracę 275 drzew. Claudio Carbone, kierownik projektu badawczego o skuteczności instalacji, twierdzi, że tego rodzaju rozwiązania łagodzące działają najlepiej w zamkniętych przestrzeniach. Jest to dobra substytucja na brak miejsca na zaaranżowanie naturalnej zieleni ${ }^{37}$. Również w krakowskim parku Jordana testuje się instalację wieży antysmogowej. Smog Free Tower ma wysokość 7 metrów i działa w oparciu o opatentowaną technologię jonizacji38. 


\section{PODSUMOWANIE}

Problem zanieczyszczenia powietrza nasila się z każdym rokiem na całym świecie. Coraz więcej miast, nie tylko tych, w których działa przemysł, jest zagrożone smogiem, zatem można uznać, że jest to problem natury globalnej. Jednakże dzięki współpracy interdyscyplinarnej inżynierów, socjologów, samorządowców oraz przede wszystkim mieszkańców zjawisko to może być ograniczone lub w przyszłości ma szansę na likwidację. Instrumenty do walki z zanieczyszczeniem powietrza są coraz bardziej powszechne, a nabyta wiedza i doświadczenie pozwala kreować miasto wolne od tego problemu. Ważne, by były chęci, determinacja oraz konsekwencja w działaniu każdego, kto w procesie uzdrawiania miast bierze udział. 


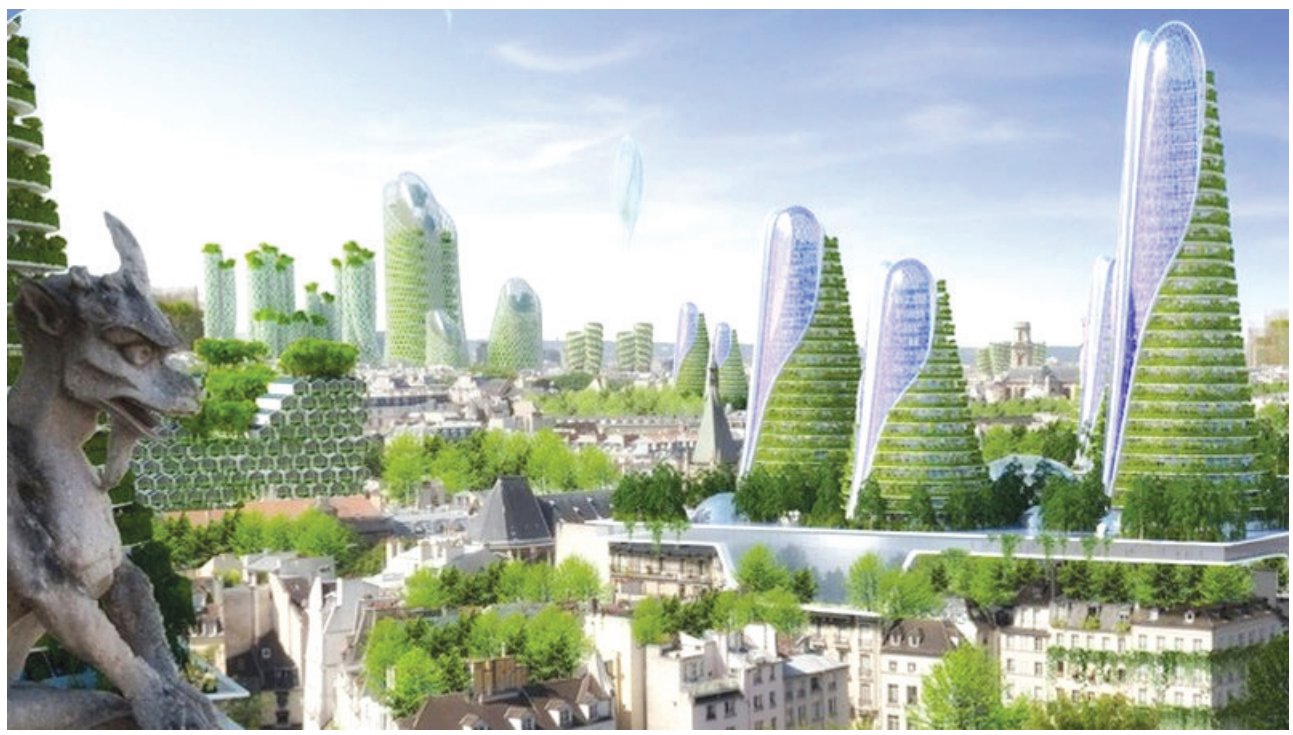

II. 1. Wizja Paryża wg Vincenta Callebauta

(źródło: https://ocdn.eu/pulscms-transforms/1/61lktkpTURBXy9iOTMxOTQ3Zj|2OWJmYmMzMTQ5NDJjZj RhYmMwNzBmMi5qcGeSIQMAAMOCwMOBjJMFzQMgzQHC; dostęp: 8.05.2018)

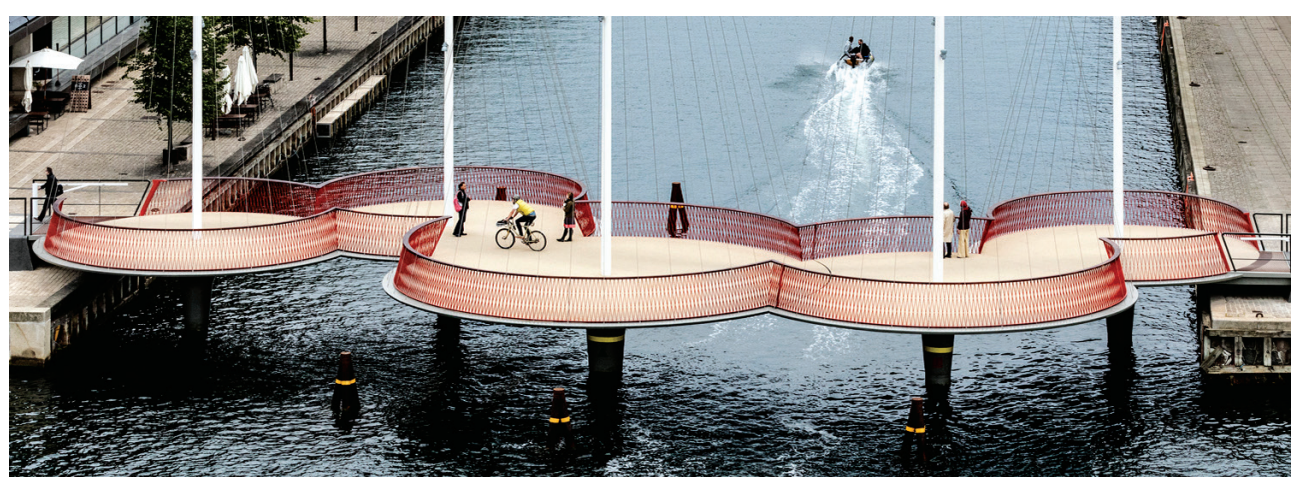

II. 2. Kopenhaska kładka piesza

(źródło: https://www.detailonline.com/fileadmin/user_upload/Cirkelbroen-Teaser-1500.jpg; dostęp: 8.05.2018) 

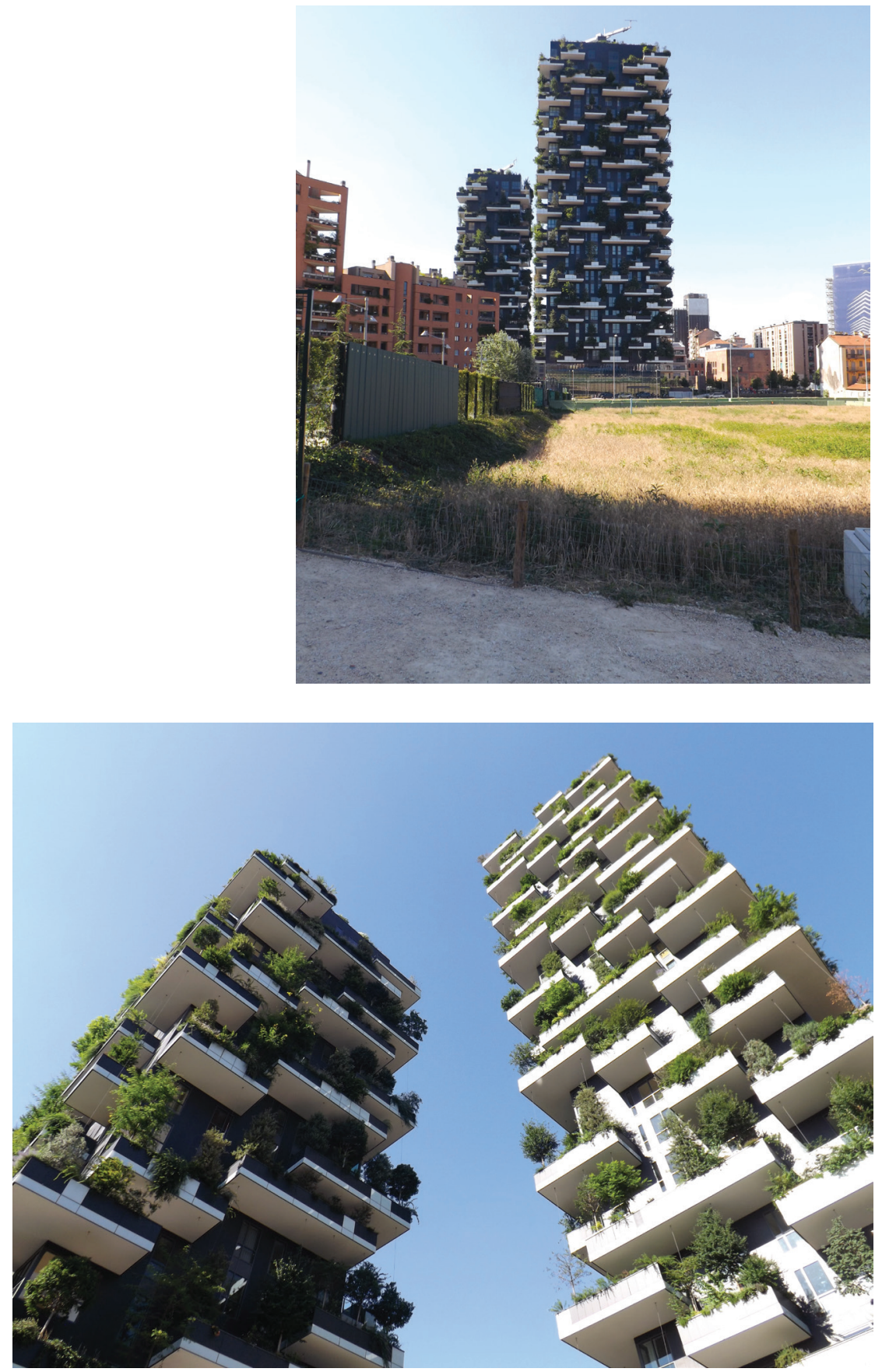

II. 3, 4. Bosco Verticale w Mediolanie (fot. M. Gyurkovich) 




II. 5. Szpital im. Manuela Gea Gonzaleza w Mexico City

(źródło: https://inhabitat.com/wp-content/blogs.dir/1/files/2013/03/Prosolve-Torre-deEspecialidaes1.jpg; dostęp: 8.05.2018)



II. 6. City Tree

(źródło: https://media.treehugger.com/assets/images/2017/06/citytree-green-cities-solutions-1. jpg.860x0_q70_crop-scale.jpg; dostęp: 8.05.2018) 


\section{PRZYPISY}

1 Polski Alarm Smogowy, Skq̨d się bierze smog?, https://www.polskialarmsmogowy.pl/polski-alarm-smogowy/smog/szczegoly,skad-sie-bierze-smog,18.html (dostęp: 8.05.2018).

2 A. Zwirowicz-Rutkowska, A. Michalik, The use of spatial data infrastructure in environmental management: an example from the spatial planning practice in Poland, Environmental Management, 2016.

3 R. Gnatowska, The urban planning in accordance with sustainable development using modeling methods. Inżynieria Ekologiczna, 33, 2013, s. 35-40.

4 A. Michalik, A. Zwirowicz-Rutkowska, M. Wojtkiewicz, Problematyka przeciwdziałania zanieczyszczeniom powietrza w pracach projektowych urbanistów i architektów w kontekście wykorzystania infrastruktur i systemów informacji przestrzennej, Acta Sci. Pol. Administratio Locorum, 16(4), 2017.

5 J. Dudek, A. Rybka, Miasto energooszczędne - wpływ kształtowania współczesnej urbanistyki i architektury na poziom emisji dwutlenku węgla, Czasopismo Techniczne, Architektura, 2010.

6 A. Faron, Wybrane czynniki struktury funkcjonalno-przestrzennej miasta, których kształtowanie może wpływać na zachowania transportowe mieszkańców, Czasopismo Logistyka, 2004, s. 3.

7 L. Laskowski, Wybrane zagadnienia fizyki miasta, Centralny Ośrodek Informacji Budownictwa, Warszawa 1987.

8 S. Różański, Budowa miasta a jego klimat, Arkady, Warszawa 1959.

9 W. Czarnecki, Planowanie miast i osiedli, t. VI. Region miasta, Państwowe Wydawnictwo Naukowe, Warszawa-Poznań 1964.

${ }^{10}$ A. Michalik, A. Zwirowicz-Rutkowska, M. Wojtkiewicz, Problematyka przeciwdziałania zanieczyszczeniom..., op. cit.

11 S. Różański, Budowa miasta a jego klimat, op. cit.

12 B. Maiheu, J. Vankerkom, S. Janssen, Improving local air quality in cities: to tree or not to tree?, Environmental Pollution, 2013.

13 T. Bartkowicz, Wpływ zagospodarowania i użytkowania terenów miejskich na zanieczyszczenie powietrza Zeszyt naukowy nr 15, Politechnika Kakowska, Kraków 1975.

${ }^{14}$ A. Hulicka, Miasto zielone. Miasto zrównoważone. Sposoby kształtowania miejskich terenów zieleni w nawiqzaniu do idei Green city, Prace Geograficzne, 2015, s. 141.

${ }^{15}$ Z. Haber, Kształtowanie terenów zieleni z elementami ekologii. Wydawnictwo Akademii Rolniczej, Poznań 2001.

${ }^{16}$ L. Laskowski, Wybrane zagadnienia fizyki miasta, op. cit.

17 T. Bartkowicz, Wpływ zagospodarowania i użytkowania terenów miejskich..., op. cit.

18 R. Gnatowska, Planowanie terenów zabudowanych..., op. cit.

19 Z. Bagieński, Miejska Wyspa Ciepła-jej wpływ na jakość powietrza, Ciepłownictwo, Ogrzewnictwo, Wentylacja, 2011, s. 4. 
20 P. Piwecki, Niska emisja dużym problemem, Przegląd Komunalny, 2016, s. 11.

${ }^{21}$ T. Kopta, Konkurencyjność transportu rowerowego, Przegląd Komunalny, 2012, s. 6.

22 A. Michalik, A. Zwirowicz-Rutkowska, M. Wojtkiewicz, Problematyka przeciwdziałania zanieczyszczeniom ..., op. cit.

${ }^{23}$ R. Tomanek, Rola bezpłatnego transportu zbiorowego w równoważeniu mobilności w miastach, Transport Miejski i Regionalny, 2017, s. 7.

${ }^{24}$ L. Garfield, 13 miast, które chcq ograniczyć ruch samochodów. W niektórych już się to udato, https://businessinsider.com.pl/lifestyle/jak-ograniczyc-ruch-samochodow-w-miescie-przyklady-rozwiazan/xfeh0jn (dostęp: 8.05.2018).

25 N. Lester, Parkingi park \& ride w Wielkiej Brytanii, Zeszyty Naukowo-Techniczne Stowarzyszenia Inżynierów i Techników Komunikacji w Krakowie, 2013, s. 1.

${ }_{26}$ M. Lewoc, Dom pasywny - wszystko, co musisz o nim wiedzieć, https://www.morizon.pl/ blog/dom-pasywny-wszystko-co-musisz-o-nim-wiedziec/ (dostęp: 8.05.2018).

27 Polskie Stowarzyszenie Budownictwa Ekologicznego, Certyfikacja wielokryterialna, LEED https://plgbc.org.pl/certyfikacja-wielokryterialna/leed/ (dostęp: 8.05.2018).

28 A. Hulicka, Miasto zielone. Miasto zrównoważone..., op. cit.

29 Sztuka Architektury, Architektura, która zmniejsza smog, http://sztuka-architektury.pl/ article/9729/1525/architektura-ktora-zmniejsza-smog-page-4 (dostęp: 8.05.2018).

30 J. Górecki, Ekologiczne inwestycje budowlane. Innowacyjne wizje Vincenta Callebauta, Przegląd Budowlany, 2009, s. 5.

31 S. Dhaliwal, Gone with the wind: Smog in Chandigarh, http://indianexpress.com/article/ cities/chandigarh/gone-with-the-wind-smog-in-chandigarh-4363233/(dostęp: 8.05.2018).

32 K. Przyjemska-Grzesik, Kraków w zieleni, czyli jak na nowo oswoić zielonq, miejskq przestrzeń. Dobre praktyki z Krakowa, http://www.ecometropolis.eu/index.php/aktualnosci/220-krakow-w-zieleni-czyli-jak-na-nowo-oswoic-zielona-miejska-przestrzen-dobre-praktyki-z-krakowa (dostęp: 8.05.2018).

33 L. Garfield, 13 miast, które chcq ograniczyć..., op. cit.

${ }^{34} \mathrm{~W}$. Yeates, Are 'smog-sucking' solutions solving air pollution?, https://dailyplanet.climate-kic.org/smog-sucking-solutions-solving-air-pollution/ (dostęp: 8.05.2018).

${ }^{35}$ Archdaily, Bosco Verticale / Boeri Studio, https://www.archdaily.com/777498/bosco-verticale-stefano-boeri-architetti (dostęp: 8.05.2018).

${ }^{36}$ Sztuka Architektury, Architektura, która zmniejsza smog, http://sztuka-architektury.pl/ article/9729/1525/architektura-ktora-zmniejsza-smog-page-4 (dostęp: 8.05.2018).

37 W. Yeates, Are 'smog-sucking'..., op. cit.

${ }^{38}$ B. Dybała, Kraków. Antysmogowa wieża czyści powietrze w parku Jordana, http://www. gazetakrakowska.pl/wiadomosci/krakow/a/krakow-antysmogowa-wieza-czysci-powietrze-w-parku-jordana-zdjecia,12924862/ (dostęp: 8.05.2018). 


\section{BIBLIOGRAFIA}

\section{Wydawnictwa książkowe}

Czarnecki W., Planowanie miast i osiedli, t. VI. Region miasta, Państwowe Wydawnictwo Naukowe, Warszawa-Poznań 1964.

Haber Z., Kształtowanie terenów zieleni z elementami ekologii, Wydawnictwo Akademii Rolniczej, Poznań 2001.

Laskowski L., Wybrane zagadnienia fizyki miasta, Centralny Ośrodek Informacji Budownictwa, Warszawa 1987.

Różański S., Budowa miasta a jego klimat, Arkady, Warszawa 1959.

\section{Czasopisma}

Bagieński Z., Miejska Wyspa Ciepła-jej wpływ na jakość powietrza, Ciepłownictwo, Ogrzewnictwo, Wentylacja, 2011, 4.

Bartkowicz T., Wpływ zagospodarowania i użytkowania terenów miejskich na zanieczyszczenie powietrza, Zeszyt naukowy nr 15, Politechnika Kakowska, Kraków 1975.

Dudek J., Rybka A., Miasto energooszczędne - wpływ kształtowania współczesnej urbanistyki i architektury na poziom emisji dwutlenku węgla, Czasopismo Techniczne, Architektura, 2010.

Faron A., Wybrane czynniki struktury funkcjonalno-przestrzennej miasta, których kształtowanie może wpływać na zachowania transportowe mieszkańców, Czasopismo Logistyka, 2004, 3.

Górecki J., Ekologiczne inwestycje budowlane. Innowacyjne wizje Vincenta Callebauta, Przegląd Budowlany,2009, 5.

Gnatowska R., Planowanie terenów zabudowanych w zgodzie z zasadami zrównoważonego rozwoju z zastosowaniem metod modelowych, Inżynieria Ekologiczna, Nr 33, 2013.

Gnatowska, R., The urban planning in accordance with sustainable development using modeling methods, Inżynieria Ekologiczna, 2013, 33, 35-40.

Hulicka A., Miasto zielone. Miasto zrównoważone. Sposoby kształtowania miejskich terenów zieleni w nawiqzaniu do idei Green city, Prace Geograficzne, 2015, 141.

Lester N., Parkingi park \& ride w Wielkiej Brytanii, Zeszyty Naukowo-Techniczne Stowarzyszenia Inżynierów i Techników Komunikacji w Krakowie, 2013, 1.

Kopta T., Konkurencyjność transportu rowerowego, Przegląd Komunalny, 2012, 6.

Maiheu B, Vankerkom J, Janssen S., Improving local air quality in cities: to tree or not to tree?, Environmental Pollution, 2013.

Piwecki P., Niska emisja dużym problemem, Przegląd Komunalny, 2016, 11.

Tomanek R., Rola bezpłatnego transportu zbiorowego w równoważeniu mobilności w miastach, Transport Miejski i Regionalny, 2017, 7.

Zwirowicz-Rutkowska, A., Michalik, A., The use of spatial data infrastructure in environmental management: an example from the spatial planning practice in Poland, Environmental Management, 2016. 


\section{Prace zbiorowe}

Michalik, A., Zwirowicz-Rutkowska, A., Wojtkiewicz, M., Problematyka przeciwdziałania zanieczyszczeniom powietrza w pracach projektowych urbanistów i architektów $w$ kontekście wykorzystania infrastruktur i systemów informacji przestrzennej, Acta Sci. Pol. Administratio Locorum, 16(4), 2017.

\section{Artykuły stron internetowych}

Archdaily, Bosco Verticale / Boeri Studio, https://www.archdaily.com/777498/bosco-verticale-stefano-boeri-architetti (dostęp: 8.05.2018).

Dhaliwal S., Gone with the wind: Smog in Chandigarh, http://indianexpress.com/article/cities/ chandigarh/gone-with-the-wind-smog-in-chandigarh-4363233/ (dostęp: 8.05.2018).

Dybała B., Kraków. Antysmogowa wieża czyści powietrze w parku Jordana, http://www.gazetakrakowska.pl/wiadomosci/krakow/a/krakow-antysmogowa-wieza-czysci-powietrze-w-parku-jordana-zdjecia,12924862/ (dostęp: 8.05.2018).

Garfield L., 13 miast, które chcq ograniczyć ruch samochodów. W niektórych już się to udało, https://businessinsider.com.pl/lifestyle/jak-ograniczyc-ruch-samochodow-w-miescie-przyklady-rozwiazan/xfeh0jn (dostęp: 8.05.2018).

Lewoc M., Dom pasywny - wszystko, co musisz o nim wiedzieć, https://www.morizon.pl/blog/ dom-pasywny-wszystko-co-musisz-o-nim-wiedziec/ (dostęp: 8.05.2018).

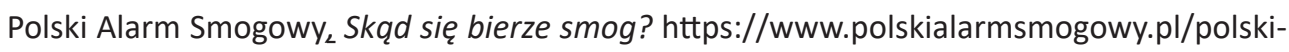
-alarm-smogowy/smog/szczegoly,skad-sie-bierze-smog,18.html (dostęp: 8.05.2018).

Polskie Stowarzyszenie Budownictwa Ekologicznego, Certyfikacja wielokryterialna, LEED https://plgbc.org.pl/certyfikacja-wielokryterialna/leed/ (dostęp: 8.05.2018).

Przyjemska-Grzesik K., Kraków w Zieleni, czyli jak na nowo oswoić zielonq, miejskq przestrzeń. Dobre praktyki z Krakowa, http://www.ecometropolis.eu/index.php/aktualnosci/220-krakow-w-zieleni-czyli-jak-na-nowo-oswoic-zielona-miejska-przestrzen-dobre-praktyki-z-krakowa (dostęp: 8.05.2018).

Sztuka Architektury, Architektura, która zmniejsza smog, http://sztuka-architektury.pl/article/9729/1525/architektura-ktora-zmniejsza-smog-page-4 (dostęp: 8.05.2018).

Yeates W., Are 'smog-sucking' solutions solving air pollution?, https://dailyplanet.climate-kic. org/smog-sucking-solutions-solving-air-pollution/ (dostęp: 8.05.2018). 